\title{
Responsive to whom? A comparison of the Mitterrand and Hollande presidencies
}

\author{
Koen Damhuis (corresponding author) \\ European University Institute \\ koen.damhuis@eui.eu \\ Johannes Karremans \\ European University Institute \\ johannes.karremans@eui.eu
}

\section{Acknowledgments:}

This article was presented during the workshop on electoral coalitions and their analytical implications at the European University Institute, 13-14 June 2016. We would like to thank the participants for their constructive feedback. We would also like to thank three anonymous reviewers for their helpful comments and suggestions. Of course, any errors remain our own. 


\begin{abstract}
This article investigates the responsiveness of the Parti socialiste towards specific social groups under the Hollande and Mitterrand presidencies. It thereby contributes to the discussion on the changing representativeness of social-democratic parties in Western Europe. The study is based on a content analysis of the governments' justifications for the annual budget. With this innovative approach it is possible to assess whether the responsiveness of a party persists at the governmental level. Through an inductive coding procedure, three categories of responsive justifications are discerned: inequality reduction, needs of specific social groups and general functioning of society. In line with its title, the article mainly focuses on the second category, identifying a shift from responsiveness to the low-income classes towards responsiveness to the middle classes. Furthermore, a corresponding transformation of the Parti socialiste is observed, from advocating expansive policies in the early 1980s to justifying restrictive policies today.
\end{abstract}




\section{Introduction}

In the spring of 2012, the French Parti socialiste won both the presidential and the legislative elections (with $51.64 \%$ and $49.93 \%$ of the votes respectively), and François Hollande became the first socialist president since 1995. The electoral victories also gave birth to the first left-wing government in the country since a decade. The change in office was saluted with enthusiasm by progressively minded political observers, who saw in Hollande and the program of his party the right answers to the austerity-dominated context of the time (Clift 2012; Hewlett 2012). Nearing the end of his mandate, the question arises to what extent the Hollande governments have actually had a leftist partisan character: have they been responsive to particular social groups, or have they obscured their political offer, as theorised in recent contributions to the literature about the failures of representative democracy (Mair 2014)? In this article, we analyse the responsiveness of the Hollande governments and compare it with the responsiveness of the first left-wing governments in the French Fifth Republic: the PS-dominated governments during François Mitterrand's first presidential mandate (1981-1986).

Our study consists of a comparative content analysis of the arguments with which the minister in charge justifies the annual budget of the government. This approach allows us to study the responsiveness of the governing party at a stage of the democratic process that has been left relatively unexplored in the literature on the representativeness of political parties. The important innovation brought by this type of analysis is that the policymaker's partisan statements are directly linked to the actual policy that the government pursues. The justifications contained in the presentation of the national budget, moreover, are informative of how the executive profiles itself in front of a very heterogeneous audience, including party supporters, government opposition and at times also international actors. These justifications are therefore highly appropriate for studying 
responsiveness within the framework of the 'responsive-responsible dilemma of partygovernment' (Bardi et al 2014), as they allow for exploring how the representativeness of governing parties survives the pressures and constraints of policy-making.

Besides its methodological contributions, the present article also sheds new empirical light on the representative character of social democratic parties. Within the vast amount of literature that has been written on this topic, recent influential studies show that the composition of social democratic electorates has substantially changed over the last few decades (Gingrich and Häusermann 2015). In our study we find that this change is also reflected on the other side of the policy process, as the PS-led government under the Hollande presidency claimed to be responsive to both the low-income classes and (especially) the middle classes, whereas under the Mitterrand presidency it claimed to be primarily responsive to the low-income classes. On top of that, we find that these different representative claims are accompanied by different budgetary policies. With this article we thus contribute in the drawing of a synthesis between what is known on the changing social composition of social-democratic electorates and the consequential different policies pursued by contemporary social-democratic governments (e.g. Häusermann and Kriesi 2015; Huber and Stephens 2015; Gingrich and Ansell 2015). Our method, moreover, could also be employed by other scholars and thereby contribute to the study of responsiveness in general.

The article is structured as follows. We first define the key concept - responsiveness - and argue how the study of justifications could potentially enhance our understanding thereof. Subsequently, we sketch where the debate in the literature on social democratic parties is at, and clarify how our study contributes to these discussions. In Section 3 we provide a description of our methodology and categorisation of the justifications, as well as an overview of the data we collected. We then continue by focusing on what we call the 'responsive' justifications of the two 
governmental periods and compare how these are distributed across the three sub-categories that we identified. After that, we zoom into the justifications referring to the demands of specific social groups and develop our argument about the way the responsiveness of the Parti socialiste is substantially different today compared to the 1980s. We conclude the article with a discussion of and reflection on our findings.

\section{Theoretical background}

Analysing responsiveness

Responsiveness is a concept that is not always defined in the same way. In general, scholars agree that it entails the idea that policies reflect citizens' preferences, but are divided when it comes to its operationalisation (see for example Bardi et al. 2014). Consequently, studies on political responsiveness differ a great deal from one another, ranging from the measurement of congruence between governmental policy positions and 'public opinion' (e.g. Ezrow and Hellwig 2014) to case studies about the extent to which governing parties follow their electoral mandate (e.g. Hofferbert and Budge 1992). These different operationalisations result from different understandings of how voters' preferences should be linked to policy outputs.

In our study of justifications, we follow Sartori's (1976) characterisation of responsive government and link it to Powell's (2004) idea of responsiveness as a representative chain. We thereby focus on the last stage of this chain, where the governing party provides information to the parliament and the public about its actions in office. In this way, we are able to analyse the extent to which the governing party still embodies the interests and preferences of its electoral constituency at the very moment of introducing new policy. Whereas studies on the political 
supply-side tend to focus primarily on party positions before Election Day (e.g. Kriesi et al 2012), our approach allows us to move further in the representative chain and explore how party representativeness persists at the policy-making stage, where it is often constrained by a variety of factors, such as socio-economic challenges or institutional constraints (Schmidt 1996).

Besides differing from the analyses of parties' programmatic offer, our analysis is also substantially distinct from studies focusing on governmental discourse, such as the Comparative Agendas Project (CAP), wherein agenda setting and issue prioritisation play a key role (e.g. GreenPedersen and Walgrave 2014; Jennings et al 2011). Instead of analysing the differences and similarities of issue prioritisation between governmental discourse and party agendas, we direct our analysis to the persistence of representative characteristics within the segments of governmental discourse that are directly linked to policy. In our view, this persistence constitutes a qualitatively more significant indicator of responsiveness. We will come back on the methodological aspects of this focus in Section 3.

Following the idea of responsiveness as a representative chain, our analysis also establishes a closer link between studies on political representation and policy studies. As mentioned before, the former have a tendency to focus on pre-electoral discourses, such as electoral manifestos (e.g. Gabel and Huber 2000) or statements reported in newspapers during the campaign (Kriesi et al 2008). Policy studies, in turn, focus on the outputs of governments, and party-scholars often try to relate these to the partisan composition of the executive. In the literature on the welfare state, for instance, there is a long-established tradition of trying to link to partisan composition of government to policy outputs (Starke 2006). Yet, the assessments of the extent to which political representation affects these policies is generally guided by different understandings of which aspects of a certain policy should feature certain partisan preferences (e.g. Allan and Scruggs 2004; 
Korpi and Palme 2003). In order to improve our understanding of responsiveness, we therefore try to find out which aspects of the budgetary policy are justified with representative claims by the policymaker.

The French Parti socialiste and the responsiveness of social democratic parties

By looking at the responsiveness of the Parti socialiste, we also engage in the difficult task of contributing to an issue that has already been studied in a large body of research, namely the changing responsiveness of social democratic parties in Europe (e.g. Kitschelt 1994; Przeworski and Sprague 1986; Scharpf 1991). In recent investigations it has been convincingly demonstrated that the sociological composition of their electorates has undergone significant changes since the 1980s, as the votes deriving from the (lower skilled) working class have increasingly been replaced by support stemming from the expanding middle classes (Gingrich and Häusermann 2015; McCrone and Keating 2015). In parallel, social democratic parties across Europe appear to have changed their approach with regards to welfare state policies, substituting policies of income replacement with social investment (Gingrich and Ansell 2015; Huber and Stephens 2015; Lister 2003). These policies, in turn, have also been strongly endorsed by the EU's social agenda (Caune et al 2011). With our study we try to establish a closer connection between the ideological change of social-democratic parties and the policies pursued by social-democratic governments.

The French Parti socialiste is a particularly interesting case because it has adhered to the electoral changes mentioned above. It has in fact lost support from working-class voters, while attracting more and more voters from the expanding middle classes (Tiberj 2013: 87; Joffré 2013: 157). Table 1 illustrates the changing sociological composition of the PS's constituency. 


\section{[Insert Table 1]}

In line with these changes, the influential PS-related think-tank Terra Nova strongly encouraged the party to increase its efforts in appealing to middle-class voters during the build-up to the 2012 presidential elections (Terra Nova 2011: 60 and 61), not in the last place because large parts of the French working classes would be increasingly attracted to the cultural and economic protectionism of Marine Le Pen's Front National (Ibid.: 15, 54-55).

Just as many other social-democratic parties in Western Europe, the PS thus faced the challenge of meeting the preferences of a socio-demographically changing clientele (Häusermann 2015, see also Przeworski and Sprague 1986). The extent to which it has succeeded to do so is relatively disputable. As mentioned above, several authors claim, for instance, that the changing social-democratic policy supply constitutes a successful case of realignment between parties and the changing preferences of voters (e.g. Kitschelt and Rehm 2015). Other scholars, by contrast, emphasise that social-democratic parties have rather obscured their programmatic offer and distanced themselves from their electorates, due to both the socio-demographic changes and the policy-constraints brought by globalisation and European integration (Lacewell 2013; Mair 2014). The obscuring of the political supply, in turn, could be brought in relation with a more general pattern in European democracies indicating that low-income groups tend to be increasingly underrepresented (Peter and Ensink 2015). It can also be linked to the professionalisation of party politicians (e.g., Fiers and Secker 2007) and the increasing social distance between politicians on the Left and their traditional clienteles: the low-income classes (e.g., Lefebvre and Sawicki, 2006). 
Moreover, the case of the Parti socialiste is particularly interesting because French governments have been struggling to meet the EU's social policy objectives of more employmentfriendly welfare states and more flexible labour markets (Bonoli and Emmenegger 2010: 831; European Commission 2016). In the European context, moreover, the Parti socialiste has often been considered as a borderline case between the northern and southern social-democrats, in the sense that it followed a more pragmatic approach in terms of ideology, whereas it maintained organisational features that are typical for the southern European Left (Merkel 1992: 166). It is therefore interesting to see how the PS succeeded in translating its ideological transformation at the policy-making level under the Hollande presidency, despite the external pressures and constraints that are related to the responsibilities of governing. In this article we therefore explore the share of representative claims in governments' justificatory discourses.

\section{The analysis of justification arguments}

Discourse is a relatively risky unit of analysis for trying to understand how policies are driven by political preferences. There is no guarantee, for instance, that policymakers, when speaking, express their actual policy attitudes. Speeches given by politicians may in fact be more characterised by rhetorical exercises rather than actual policy criteria (Charteris-Black 2011). With our analysis, however, we reduce these risks in two ways. First, and similar to the CAP studies, we focus on legislative discourse, wherein policy makers are expected to behave consistently with their statements (Van der Veen 2011: 31). Second, and following this logic, we focus on discourse that provides an explanation for the origins, criteria and objectives of policies. In other words, we do not focus on a whole body of text, but select those passages that are closely linked to actual decisions, and that therefore, in our view, are more likely to provide accurate information about 
the role of political representation in public office. While the CAP studies have a more quantitative accent, our analysis puts more emphasis on the qualitative selection of the data.

The annual presentations of the government's budget, moreover, are particularly relevant for both their content and their setting. Budgetary policies, in fact, are not an isolated policy area but are rather connected to all socio-economic spheres of government activity, and consequently have important repercussions for a wide range of actors, including pensioners and international financial markets. As these speeches are given in front of the whole parliament, they expose the minister to criticism from both the party supporters as well as the government's opposition. The fact that these speeches are an annual formal recurrence, moreover, enables us to keep many factors constant, thereby facilitating a comparison of the responsiveness of the Parti socialiste in the two periods under study.

The presentations of the budget are held each year in the month of October by the minister of economy and finance, during the discussion of the general finance law in the French Assemblée Générale. We analysed all budget speeches of PS-dominated governments during the first mandate of François Mitterrand and that of François Hollande: ${ }^{1}$

Mitterrand governments: Laurent Fabius (27 October 1981 and 26 October 1982), Jacques Delors (19 October 1983), Pierre Bérégovoy (16 October 1984 and 16 October 1985).

\footnotetext{
${ }^{1}$ All budget speeches can be found on the official website of the French Assembly. See: http://archives.assembleenationale.fr/7/cri/ for the Mitterrand governments, and http://www.assemblee-nationale.fr/14/debats/ for the Hollande governments (accessed on 10 April and 11 December 2016)
} 
Hollande governments: Pierre Moscovici (16 October 2012 and 15 October 2013),

Michel Sapin (14 October 2014, 13 October 2015, 18 October 2016).

It is important to note that in all cases the minister delivering the speech was a member of the Parti socialiste. Following our understanding of responsiveness as a representative chain, the justifications of the PS minister should thus reflect the partisan discourse.

To gather the justifications from the speeches of the minister, we first identified those passages referring to a specific policy or to the general government's action, and then coded the phrases that described the criteria, the origins and the reasons behind the government's budget policies. For instance, from the following passage, we coded that the reduction of income taxes contained in the last budget of the Hollande presidency is driven by the government's wish to improve the living conditions of the poorest and the middle classes and contribute to the progressiveness of the overall tax regime.

Ce budget mettra en ouvre plusieurs mesures qui poursuivront notre action en faveur du pouvoir d'achat des plus démunis et des classes moyennes. Une quatrième baisse consécutive de l'impôt sur le revenu est inscrite dans ce projet de loi de finances [...] Ces mesures ont clairement renforcé la progressivité de l’impôt sur le revenu
This budget will exert several measures in line with our procedures in favour of the spending power of the poorest and the middle classes. A fourth consecutive reduction of income taxes is part of this budget plan [...] These measures have clearly contributed to the progressiveness of income taxes 


\section{Michel Sapin, 18 October 2016}

More specifically, the underlined segment of the text concerns the policy that is being referred to and the pieces of text in bold constitute the actual justification-propositions that constitute the heart of our analysis. In total, we collected 940 of these propositions (464 for the Mitterrand period, 476 for the Hollande period).

Due to the broadness of the audience, the policies are not only justified according to responsive criteria, but also to what might be called responsible criteria (Sartori 1976; Mair 2014; Karremans 2016). That is, the technical duties of the government with regards to the economy and public finances. These responsible justifications are beyond the scope of this article and will be analysed in a future study (Karremans and Damhuis forthcoming). Our focus here is centred on the responsive justifications of the PS.

In Section 4, we will explain how these justifications coincide with the government's social concerns and specific policy goals. At the same time, we also kept track of the type of measures, that is, the policy instruments that the latter refer to. More specifically, we made a distinction between policy instruments that concretely expanded the governmental activities (such as increases in expenditure and higher levels of taxation) from those that restrict the latter (such as budgetary cuts and tax relief for certain social groups). We labelled these categories respectively as 'expansive' and 'restrictive' policy instruments. Finally, we also encountered references to policy instruments without concrete financial measures. In this case, we classified the references as 'general' policy. The aim of this second layer of our analysis is to get a better understanding of what the responsiveness towards particular social groups actually entails. Section 5 will be devoted to this part of the analysis. 


\section{A dilution of ideologically distinctive responsiveness}

In contrast to responsible justifications, responsive arguments justify the government's policy according to its ideological character. To our understanding, the responsiveness of a leftist government is characterised by the special attention it displays for social matters, such as the reduction of inequality or the investment in public services. It is through this kind of issues that social democratic parties generally distinguish themselves from the political right (see also Bobbio 1996; Kriesi et al 2008; Huber and Stephens 2015). Consequently, the responsiveness of the PS is determined by the way in which its ministers in government address these issues. For instance, when the minister claims that his budget is just because it provides support to the poorest members of society, we consider those justifications to be characteristically leftist and thereby responsive.

For the Hollande governments, these claims constitute $29 \%$ of all justifications, whereas for the Mitterrand governments their share is $35 \%$. This difference suggests that the PS-led governments were slightly more attentive to social issues during the Mitterrand presidency. When looking more closely at the justifications, we will see, however, that this difference is not only numerical. More importantly, the PS under the presidency of François Hollande also had different social concerns that seem to indicate a more distant attitude towards society, wherein no distinction is drawn between different social categories.

\section{Fewer references to inequality reduction}

To analyse the responsive justifications, we subdivided them into three broad groups. This categorisation was developed inductively by aggregating the specific references to societal matters 
(see also Appendix 1). The differentiation however also speaks to more deductively constructed theories about modes of representation (e.g. Saward 2008), as they differ in the extent to which they refer to the material interests of social groups versus ideas about what government should do for society. The three broad categories are: (1) reduction of inequality, (2) needs of specific social groups, and (3) general functioning of society. ${ }^{2}$ The categories differ concerning the way in which the government profiles itself as an intervening redistributive actor. Category 1 contains typical socialist claims about redistributing wealth from the rich to the poor. Category 2 refers to the demands of specific social groups for which the government decides to be responsive. Category 3 , in turn, contains those claims that depict society as a singular entity and justify the government's action contributing to its general functioning.

Figure 1 illustrates the share that each category has in the responsive justifications of the Hollande and Mitterrand presidencies.

[Insert Figure 1]

As can be seen, the governments differ significantly in the weight they give to categories one and three. This difference, in turn, signals a different perception of the PS about how it should deal with societal matters as a governmental actor.

\footnotetext{
${ }^{2}$ Among these 940 justifications, 7 propositions belong to a residual category which might be described as international solidarity (4 among the Mitterrand governments and 3 among the Hollande governments).
} 
The category 'reduction of inequality' contains those justifications referring to the traditional social democratic commitment of redistributing wealth across society, and are generally associated with policies in which the richer segments of society get taxed and the government's plans to extend social provisions for the less well-off. Historically, this type of claims constitutes an important component of the political identity of the Parti socialiste, and has been challenged during the last few decades by the rise of so-called "neoliberal" ideas in international economic debates. Nonetheless, this type of justifications is present in the discourse of both governments, as the following examples illustrate:

Est-il acceptable, mesdames, Is it acceptable, ladies and gentlemen, messieurs, que $5 \mathrm{p} .100$ des Français that 5 per cent of the French population détiennent à eux seuls près de 40 p. $100 \quad$ owns almost 40 percent of the wealth of du patrimoine de notre pays alors que $\quad$ our country whereas the poorest 50 per les 50 p. 100 les moins riches de nos cent of our fellow citizens only concitoyens n'en possèdent que possesses a few per cent? The ambition quelques pour cent? L'ambition du of the government is to correct these Gouvernement est de corriger ces excessive disparities, or in any case, to disparités excessives, ou en tout cas prevent them from growing any further d'éviter qu'elles n'augmentent encore. 
En supprimant plusieurs niches By closing off several tax loopholes, we fiscales, nous rendons l'impôt plus make taxation fairer and our system juste et notre système plus more redistributive.

redistributif.

Pierre Moscovici, 15 October 2013

From these passages we can see how governments in the two periods under study integrate justifications on inequality reduction. As can be observed in Figure 1, however, the relative share of these justifications has been remarkably inferior under the Hollande presidency. This difference persists also when we take the so-called tournant de la rigeur into consideration during the Mitterrand presidency, as these justifications also represented roughly $30 \%$ of the responsive justifications in the budget speeches between 1983 and 1985. In the Hollande period, by contrast, these justifications were mainly present in the first budget speech and tended to disappear in the central part of the term in office, and reappear only in the last budget speech.

More references to the general functioning of society

The trend is almost opposite when looking at the justifications referring to the third broad category, namely the general functioning of society. These claims do not make any distinction between social groups, and are generally used to justify investments in education and other sorts of public investment such as health and security, as well as economic policies that protect the purchasing 
power of all citizens (irrespective of social positions) a certain extent, these claims are also less ideologically distinctive than the other responsive justifications, as the next excerpts exemplify:

L'effort de formation et de recherche sera lui aussi intensifié. Le budget prévoit, à cet égard, un accroissement important des moyens affectés à ces actions.
The effort put into education and research will also be intensified. In this respect, the budget contains an important increase in the means assigned to these actions.

Pierre Bérégovoy, 16 October 1984

[La croissance] passera aussi par [Growth] will also be achieved through the l'amélioration de la situation économique improvement of the economic and social et sociale des Français. En vérité, il s'agit situation of the French. In truth, these are là de deux objectifs qui se renforcent two mutually reinforcing objectives. Let's mutuellement. N'opposons pas ménages et not oppose households and businesses. entreprises.

Pierre Moscovici, 15 October 2013

The category 'general functioning of society' thus contains a wide share of justifications which share the commonality of referring to social issues. They thereby highlight the need for societal 
improvement rather than emphasising policies aimed at particular social groups. Another characteristic of these claims is the emphasis on the need for social unity, as Pierre Moscovici's proposal illustrated, wherein he justifies the government's action as an effort to 'not oppose households and businesses'.

When comparing the responsiveness of the two presidential time periods, the justifications of the Hollande government tend to be more characterised by this type of claims (40 versus $32 \%$ ). Besides this quantitative shift, it is interesting to notice that justifications belonging to our third category are also becoming more and more general in qualitative terms. Under the Mitterrand presidency, in fact, the emphasis was put much more on spending commitments towards education and culture. Under the Hollande presidency, instead, the justifications put more emphasis on the spending power of French citizens in general, thereby emphasising how the government is committed not to oppose social groups.

These developments, and in particular the emphasis on the wish not to oppose social groups, are strongly related to the different social groups that are addressed by the PS under the two presidencies and the policy instruments it invoked. In the next section we will show how.

\section{Changing policy clienteles, changing policy instruments}

Whereas the two periods under study feature significant differences when it comes to the proportions of justifications relating to the reduction of inequality and the general functioning of society, the relative share of our second category (needs of social groups) stays rather stable over time (around 33\%). Yet, the Hollande governments did not address the same social groups as the Mitterrand executives. Moreover, the policy instruments employed to meet the demands of these 
groups differ substantially. This corroborates the idea that the PS has adapted its policy supply to the different sociological composition of the PS constituencies between the two time periods (Häusermann 2015; Huber and Stephens 2015). In this section, we will show that the contemporary PS, besides being more concerned with the demands of the middle classes, also tries to meet such demands with radically different policy instruments.

From the low-income classes to the middle classes

Both Hollande and Mitterrand governments dedicate about a third of their responsiveness justifications to the needs of particular social groups. Yet they vary when it comes to the extent to which they profile themselves as advocates of the demands of different social groups. Figure 2 reports the relative proportions of these groups within our second category of responsive justifications.

[Insert Figure 2]

Three remarkable changes meet the eye. First, employees - a traditional electoral clientele of the Left (Boy and Mayer 1997) - are considerably less referred to in the contemporary justifications, with percentages dropping from about 15 to 2 when comparing the Mitterrand with the Hollande governments. Second, a similar pattern can be observed for the unemployed, whereby the percentages decrease from about 15 to 4 . The third and most staggering change concerns the relative decline in responsive justifications towards the low-income classes and the notable 
appearance of the middle classes in the PS budget speeches. From a complete absence in the 1980s, middle classes (including explicit references to middle income groups) nowadays constitute the main social group to which the PS claims to be responsive.

The increased attention to the middle classes, moreover, is strongly paired up with the above-mentioned claims not to oppose different social groups, as the following passage of minister Michel Sapin illustrates:

\begin{tabular}{|c|c|}
\hline Nous n'opposons pas les catégories & We do not oppose social categories; we \\
\hline sociales entre elles, nous n'avons pas deux & do not have two policies according to one \\
\hline politiques en fonction des uns et des autres. & group or another. We only have one single \\
\hline Nous avons un principe et un seul : l'impôt & principle: taxation must be reduced, first \\
\hline doit baisser et en priorité pour le caur des & and foremost for the heart of the middle \\
\hline classes moyennes & classes \\
\hline
\end{tabular}

Michel Sapin, 13 October 2015

This tendency of de-conflictualisation is indicative of the pattern we described before: the quantitative and qualitative shift towards a fading of the party's ideological distinctiveness and increased preoccupation with the general functioning of society. The shift towards meeting the interests of the middle class thus seems to be strongly related to this new policy attitude. 
Whereas the PS showed an increasing attention towards the middle classes during the Hollande period, the party seemed to be more determined in profiling itself as a proactive advocate of the poorest parts of the population during the Mitterrand years, as the following passage also illustrates.

Bien entendu, l'État ne peut pas réduire [...] les impôts de ceux qui ne paient pas d'impôt à l'État. C'est aussi simple que cela. Cela veut-

il dire que rien n'est fait pour les plus modestes? Au contraire, depuis 1981, leur situation s'est améliorée — on nous l'a assez reproché !
Of course, the state cannot reduce $[\ldots]$ the taxes of those who do not pay any taxes to the state. It's as simple as that. But is this to say that we did not do anything for the poorest? Quite the contrary, since 1981, their situation has improved - we have been criticised sufficiently for it!

Pierre Bérégovoy, 16 October 1984

With this statement the minister justifies the general policy of the government. It is interesting to note that this passage is from 1984. That is, after the famous tournant de la rigueur, when the government saw itself forced to reverse its expansive policies (Gourevitch 1986). With this and similar statements, the government still claims to be responsive towards the lower social classes.

The references towards the social groups remain relatively constant throughout the term in offices of both presidencies. Also after 1983, the PS ministers emphasised their commitment to safeguard the interests of the low-income classes, despite the budgetary cuts and reforms they 
started to pursue (Ross 1987; Christofferson 1991). Under Hollande, the PS profiled itself as a caretaker of both the lower and the middle classes in all five years of government. What changed, moreover, is the way in which the justifications are associated with the actual policies during the two time periods, as will be shown below.

\section{From expansive to restrictive policies}

Both Mitterrand and Hollande governments faced adverse economic conditions that limited the extent to which they could increase social spending (Gourevitch 1986; Schäfer and Streeck 2013). Surprisingly, however, the share of responsive justifications decreases only marginally in the second half of the term in office. In both cases, the PS continued to refer to its partisan commitments even when it could not pursue social expenditure policies. The difference between the two presidencies, however, is that the PS's responsive justifications during the Mitterrand period hardly ever refer to restrictive measures and, after 1983 they mainly relate to the government's general policy, as the previous passage from the 1984 budget speech illustrated. During almost the entire Hollande presidency, however, a large share of the responsive justifications refers to budgetary cuts and reduction in taxation. Table 2 illustrates the annual distribution of the responsive justifications across the different policy types.

[Insert Table 2] 
In both cases, the responsive justifications referring to expansive policies tend to disappear towards the end of the term in office, which signals how difficult it was in both cases to increase public expenditure. For the Mitterrand governments, however, the restrictive measures the government was forced to pursue were not justified with responsive justifications. In this period, the latter only referred to policy-packages. Under Hollande, by contrast, the responsive claims also largely justified the restrictive measures. Together with the scarcer attention given to the reduction of inequality and the interests of the lower social classes, these findings shed a new light on the changing responsiveness of the PS.

First of all, the larger share of responsive justifications referring to restrictive measures signals that the PS perceives budgetary cuts and reduction in taxation as responsive to the preferences of (parts of) its electorate. This seems to be in line with the idea that social-democratic parties have adapted their policy supply to the preferences of the middle class, who - despite favouring a certain level of redistribution - also support decreases in taxation and a responsible way of dealing with public expenditures (Huber and Stephens 2015; Kitschelt and Rehm 2015). This interpretation seems to find even stronger confirmation when zooming into the justifications referring to the needs of specific social groups. Table 3 illustrates the same pattern as Table 2, but focussing only on the justifications referring the second category of our responsive justifications.

[Insert Table 3]

As can be seen, the pattern here is even stronger. The distribution shown in the table strongly suggests that the responsiveness of the PS in the 1980s was strongly dependent on the possibility 
to redistribute public resources in favour of the poor. In the 2010s instead, the restrictive measures that were pursued throughout the whole term in office were still justified with responsive arguments that largely referred to the interests of the middle classes.

Second, besides the stronger focus on the middle classes, it also seems that in the $2010 \mathrm{~s}$ the PS is more willing and more capable in moving within the restricted space it can manoeuvre. The following passage, for example, exemplifies how the cost savings it succeeded in achieving are subsequently transformed at the advanced of both middle- and low-income households.

J'insisterai maintenant sur l'importance des économies, car c'est grâce à elles que nous pouvons financer les baisses de prélèvements, en particulier la réforme du bas du barème de l'impôt sur le revenu qui vous est proposée. C'est grâce à ces économies que nous pouvons redonner 3,2 milliards d'euros aux ménages moyens et modestes.
I will now insist on the importance of the cost savings, because it is thanks to them that we can finance the decrease of taxes, in particular the reform of the income tax brackets that is proposed to you. Thanks to these cost savings, we can give back 3.2 billion euros to the middle-income and low-income households.

Michel Sapin, 14 October 2014

This and similar passages corroborate the idea that the PS has shifted its policy supply to the preferences of its new electorate (Huber and Stephens 2015; Kitschelt and Rehm 2015), as they 
profile the government as somehow favouring redistribution, but still within the limits posed by responsible criteria of public expenditure policy. At the same time, however, these justifications may also suggest that there is less room for distributive policies within the governmental sphere, thereby confirming the more pessimistic views about the future of the political left and partydemocracy in general (Mair 2014).

\section{Conclusions and perspectives}

In this article we have shown that the PS governments of the Hollande presidency have aimed to be more responsive to the middle classes when compared to the governments of the first Mitterrand presidency. This finding is in line with recent studies on the changing electoral composition of social-democratic parties in Europe, according to which the working class is no longer their core clientele (Gingrich and Häusermann 2015). The social-democratic electorate has become sociologically more variegated, maintaining, however, a preference for a government that works towards a reduction of economic inequalities and more social cohesion (Huber and Stephens 2015). Our findings confirm these recent insights, highlighting however also some relevant changes in the policy-attitude of the PS.

The content of the justifications not only reveal a change in the social addressees of the PS, but also in a different self-profiling when referring to society and social groups. While in the 1980s the PS presented itself very clearly as an advocate of the interests of the lower social classes, the party profiles itself more as a caretaker of society in general today, wishing not to oppose social groups. This change goes hand in hand with the shift of attention towards the middle classes, and is also accompanied by a relatively weaker attention to the party's historical redistributive goals. 
On top of that, these patterns also seem to be related to a different approach of the party towards budgetary cuts and decreases in taxation. Whereas the responsiveness of the PS seemed to be much more dependent on its capacity to spend in the 1980s, the party appears to be much more aware today of the constraints that a government may face in the field of social expenditure. Consequently, it seems to be more cautious in its partisan claims and tries to meet the preferences of its constituencies within the limits posed by the economic and financial constraints. This different attitude, in turn, is likely to be facilitated by the preferences of the new middle classes, who are unlikely to see a government that irresponsibly increases public expenditure (Huber and Stephens 2015). In many ways, thus, our findings corroborate the idea that the PS has successfully adapted its policy supply to the changing preferences of its electorate.

At the same time, our findings do leave room for further discussion about the idea that governing today has become more difficult and that, consequently, the options of being politically responsive have become more limited (Mair 2014). To some extent, our findings also signal that the responsiveness of the contemporary PS has become less ideological and more pragmatic. This could be interpreted as an obscuration of its political supply (Mouffe 2005; Gusenbauer and Skrzypek 2013; Lacewell 2013). The restrictive measures with which it tries to meet the demands of its electorate, moreover, might entail the risk of alienating the less well-off sections of the of the party's electorate. In turn, this trend taps into what in recent contributions have labelled 'differential responsiveness'. That is, the under-representation of the low-income groups in European democracies (Peters and Ensink 2015). To further test these ideas, our methodology could be applied to contemporary governments in other European countries. 


\section{Bibliography}

Allan, James P., and Lyle Scruggs (2004). 'Political partisanship and welfare state reform in advanced industrial societies', American Journal of Political Science 48:3, 496-512.

Bardi, Luciano, Stefano Bartolini, and Alexander Trechsel (2014). 'Responsive and responsible? The role of parties in 21st century politics.' West European Politics 37:2, 235-52.

Bobbio, Norberto, and Allan Cameron (1996). Left and Right: The significance of a political distinction. Cambridge: Polity Press.

Bonoli, Giuliano, and Patrick Emmenegger (2010). 'State-Society Relationships, Social Trust and the Development of Labour Market Policies in Italy and Sweden', West European Politics, 33:4, 830-850.

Boy, Daniel and Nonna Mayer (1997) 'Secteur public, secteur privé: un nouveau conflit de classe', in : Nonna Mayer (ed.), Les modèles explicatifs du vote. Paris: L'Harmattan, pp. 111-31.

Caune, Hélène, Sophie Jacquot, and Bruno Palier (2011). 'Social Europe in action: the evolution of EU policies and resources', in: Paolo Graziano, Sophie Jacquot, Bruno Palier (eds.), The EU and the Domestic Politics of Welfare State Reforms: Europa, Europae, New York: Palgrave Macmillan, pp. 19-47.

Charteris-Black, Jonathan (2011). Politicians and rhetoric: The persuasive power of metaphor. New York: Palgrave Macmillan.

Christofferson, Thomas R. (1991) The French Socialists in Power, 1981-1986. From Autogestion to Cohabitation. Newark: University of Delaware Press.

Clift, Ben (2012). 'Le Changement? French Socialism, the 2012 Presidential Election 
and the Politics of Economic Credibility amidst the Eurozone Crisis.' Parliamentary Affairs 66:1, 106-23.

European Commission (2016) 'Employment and Social Developments in Europe 2015', Luxembourg: Publications Office of the European Union.

Ezrow, Lawrence, and Timothy Hellwig (2014), 'Responding to Voters or Responding to Markets? Political Parties and Public Opinion in an Era of Globalization', International Studies Quarterly, 58:4, 816-27.

Fiers, Stephaan and Ineke Secker, 2007. 'A Career through the Party: The Recruitment of Party Politicians in Parliament', in: Maurizio Cotta and Heinrich Best (eds.) Democratic Representation in Europe: Diversity, Change and Convergence, Oxford: Oxford University Press, pp. 136-159.

Gabel, Matthew J., and John D. Huber (2000). 'Putting Parties in Their Place: Inferring Party Left-Right Ideological Positions from Party Manifestos Data', American Journal of Political Science, 44:1, 94-103.

Manifestos Data. American Journal of Political Science, 44:1: 94-103.

Gingrich, Jane, and Ben W. Ansell (2015). 'The Dynamics of Social Investment:

Human Capital, Activation, and Care', in Pablo Beramendi, Silja Häusermann, Herbert Kitschelt and Hanspeter Kriesi (eds.), The Politics of Advanced Capitalism. New York: Cambridge University Press, 282-304.

Gingrich, Jane, and Silja Häusermann (2015). 'The Decline of the Working-Class Vote, the Reconfiguration of the Welfare Support Coalition and Consequences for the Welfare State', Journal of European Social Policy, 25:1, 50-75.

Gourevitch, Peter (1986). Politics in Hard Times: Comparative Responses to International 
Economic Crises. Ithaca: Cornell University Press.

Green-Pedersen, Christoffer, and Stefaan Walgrave, eds (2014). Agenda setting, policies, and political systems: a comparative approach. University of Chicago Press.

Gusenbauer, Alfred, and Ania Skrzypek (2013). 'The next social contract. Progressive Politics after an era of plenty', in Olaf Cramme, Patrick Diamond and Michael McTernan (eds.) Progressive Politics after the Crash. Governing from the Left. London and New York: I.B. Tauris: 229-238.

Häusermann, Silja (2015). 'Electoral realignment and the Position of Social Democratic Parties on Welfare Policies', Paper presented at the 22nd International Conference of Europeanists, Paris, $9^{\text {th }}$ July.

Hewlett, Nick (2012). 'Voting in the Shadow of the Crisis. The French Presidential and Parliamentary Elections of 2012', Modern \& Contemporary France, 20:4, 403-20.

Hofferbert, Robert I, and Ian Budge (1992). 'The Party Mandate and the Westminster Model: Election Programmes and Government Spending in Britain, 1948-85', British Journal of Political Science, 22(2): 151-82.

Huber, Evelyne, and John D. Stephens (2015). 'Postindustrial Social Policy', in Pablo Beramendi, Silja Häusermann, Herbert Kitschelt and Hanspeter Kriesi (eds.), The Politics of Advanced Capitalism. New York: Cambridge University Press, 259-81.

Iversen, Torben, and David Soskice (2015). 'Democratic Limits to Redistribution: Inclusionary versus Exclusionary Coalitions in the Knowledge Economy', World Politics, 67:2, 185-225.

Jennings, Will, Shaun Bevan, and Peter John (2015). 'The agenda of British government: The speech from the throne, 1911-2008', Political Studies 59:1, 74-98. 
Joffré, Jérôme (2013). 'La victoire étroite de François Hollande', in: Pascal Perrineau (ed.) Le vote normal. Les élections présidentielle et législatives d'avril-juin 2012, Paris, Presses de Sciences Po, pp. 133-160.

Karremans, Johannes (2016). 'State VS Voters: On which side do (Labour) parties stand?' Unpublished manuscript. Florence: European University Institute.

Karremans, Johannes, and Koen Damhuis (forthcoming). 'The changing dynamics of governmental responsibility in France between the 1980s and today.

Kitschelt, Herbert (1994). The Transformation of European Social Democracy. Cambridge: Cambridge University Press.

Kitschelt, Herbert, and Philipp Rehm (2015). 'Party Alignments. Change and Continuity', in Pablo Beramendi, Silja Häusermann, Herbert Kitschelt and Hanspeter Kriesi (eds.), The Politics of Advanced Capitalism. New York: Cambridge University Press, 179-201.

Korpi, Walter, and Joakim Palme (2003). 'New politics and class politics in the context of austerity and globalization: Welfare state regress in 18 countries, 1975-95', American Political Science Review, 97:3, 425-446.

Kriesi, Hanspeter, Edgar Grande, Romain Lachat, Martin Dolezal, Simon Bornschier, Timotheos Frey (2008) West European Politics in the Age of Globalization, Cambridge: Cambridge University Press.

Lacewell, Onawa P. (2013) 'Beyond Class: Class Party Programmatic Responses to Globalization Pressures and Cleavage Change', APSA 2013 Annual Meeting Paper.

Lee, Alexander, and Timothy Stanley (2006). The End of Politics. London: Politico's Publishing Ltd. 
Lefebvre, Rémi, and Frédéric Sawicki (2006). La société des socialistes : Le PS aujourd'hui. Paris: Éditions du Croquant.

Lister, Ruth (2003). 'Investing in the Citizen-Workers of the future: Transformations in Citizenship and the State under New Labour', Social Policy \& Administration, 37:5, 42743.

Mair, Peter (2014). 'Representative versus Responsible Government', in Peter Mair, On Parties, Party Systems and Democracy. Colchester: ECPR Press, 581-96.

McCrone, David, and Michael Keating (2015). 'Social democracy in crisis: outlining the trends in western Europe', in: Michael Keating and David McCrone (eds) The crisis of social democracy in Europe. Edinburgh: Edinburgh University Press, 28-46.

Merkel, Wolfgang (1992). 'After The Golden Age: Is Social Democracy Doomed to Decline?', in: Christiane Lemke and Gary Marks (eds) The Crisis of Socialism in Europe. Durham: Duke University Press, 136-170.

Mouffe, Chantal (2005). 'The "End of Politics" and the Challenge of Right-wing Populism', in Francesco Panizza (ed.) Populism and the Mirror of Democracy. London: Verso, pp. 5071.

Peters, Yvette, and Sander J. Ensink (2015). 'Differential responsiveness in Europe: The effects of preference difference and electoral participation'. West European Politics, 38:3, 577600.

Powell G. Bingham (2004). 'The chain of responsiveness', Journal of Democracy 15:4, 91-105.

Ross, George (1987). 'From one Left to Another. Le Social in Mitterrand's France', in: George 
Ross, Stanley Hoffmann and Sylvia Malzacher (eds.) The Mitterrand Experiment: Continuity and Change in Modern France. Oxford: Polity Press, pp. 199-216.

Sartori, Giovanni (1976). Parties and party systems: A framework for analysis. Cambridge: Cambridge University Press.

Saward, Michael (2008). 'Making representations: modes and strategies of political parties', European Review 16:3, 271-86.

Schäfer, Armin, and Wolfgang Streeck (eds) (2013). Politics in the Age of Austerity. Cambridge: Polity Press.

Scharpf, Fritz W. (1991). Crisis and choice in European social democracy. Ithaca: Cornell University Press.

Schmidt, Manfred G. (1996). 'When parties matter: A review of the possibilities and limits of partisan influence on public policy', European Journal of Political Research, 30:2, 155183.

Starke, Peter (2006). 'The politics of welfare state retrenchment: A literature review.', Social Policy \& Administration 40.1: 104-120.

TerraNova (2011) Gauche : quelle majorité électorale pour 2012?, Projet 2012, Contribution $n^{\circ} 1$. Available at: http://nova.fr/system/contents/files/000/000/704/original/Rapport_Terra_Nova_Strat_gie _lectorale.pdf?1436783291 (accessed 16 May, 2016).

Tiberj, Vincent (2013) Votes de gauche, votes de droite, hier et aujourd'hui. In : Vincent Tiberj (ed.) Des votes et des voix. De Mitterrand à Hollande, Paris, Champ social éditions, pp. 84-94.

Van der Veen, Maurits A. (2011). Ideas, Interests and Foreign Aid, New York and London: 
Cambridge University Press. 
APPENDIX: CODED JUSTIFICATIONS PER YEAR AND TYPE OF POLICY*

\begin{tabular}{|c|c|c|c|c|c|c|c|c|c|c|c|c|c|c|c|c|c|c|c|c|c|c|c|c|c|c|c|c|c|c|}
\hline \multirow[b]{2}{*}{ Justification category } & \multicolumn{3}{|c|}{1981} & \multicolumn{3}{|c|}{1982} & \multicolumn{3}{|c|}{1983} & \multicolumn{3}{|c|}{1984} & \multicolumn{3}{|c|}{1985} & \multicolumn{3}{|c|}{2012} & \multicolumn{3}{|c|}{2013} & \multicolumn{3}{|c|}{2014} & \multicolumn{3}{|c|}{2015} & \multicolumn{3}{|c|}{2016} \\
\hline & E & G & $\mathbf{R}$ & E & G & $\mathbf{R}$ & E & G & $\mathbf{R}$ & E & G & $\mathbf{R}$ & E & G & $\mathbf{R}$ & E & G & $\mathbf{R}$ & E & G & $\mathbf{R}$ & $\mathrm{E}$ & G & $\mathbf{R}$ & E & G & $\mathbf{R}$ & E & G & $\mathbf{R}$ \\
\hline 1.1. Reduce inequality & 14 & 6 & & 2 & 2 & & 3 & 7 & & 2 & 11 & 1 & 1 & 8 & & 2 & 14 & 3 & 1 & 5 & & 1 & & & & & & & 2 & 3 \\
\hline 2.1 low-income classes & 1 & & & 3 & & 1 & & 3 & 2 & 2 & 3 & & & & 1 & 1 & 3 & & & 1 & 2 & & 1 & 2 & & & 1 & & 2 & 2 \\
\hline 2.2 middle classes & & & & & & & & & & & & & & & & & 1 & & & 1 & 1 & & & 2 & & 1 & 6 & & 2 & 2 \\
\hline 2.3 unemployed & 1 & & & & & & & & & 1 & 1 & & 1 & 3 & & & & & 1 & & & & & & & & & 1 & & \\
\hline 2.4 Employees & 1 & 1 & 1 & 1 & & & & & 2 & & 1 & & & & & & & & & & & & & & & & 1 & & & \\
\hline 2.5 Families & 1 & & & 1 & & & 2 & & 1 & 1 & & & & & & 1 & & & & 1 & & & & & & & 1 & & & \\
\hline 2.6 Young citizens & 1 & & & & & & & 2 & & 1 & 1 & & & & & 1 & & & 1 & & & 1 & & & 1 & & 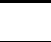 & & & \\
\hline 2.7 Elderly & 1 & & & & & 1 & & & & 2 & & & & & & & & & & & 1 & & & & & & 1 & & & 3 \\
\hline 2.8 General needs of social groups (other) & & & & & & & & & & & & & & & & & 1 & & & & & & & & & & & & & \\
\hline 2.9 Future generations (other) & & & & & & & & & & & & & & & & & & 1 & & & & & & & & & & & & \\
\hline 2.10 Handicapped adults (other) & & & & & & & & & & 1 & & & & & & & & & & & & & & & & & & & & \\
\hline 2.11 Welfare recipients (other) & & & & & & & & 1 & & & & & & & & & & & & & & & & & & & & & & \\
\hline 2.12 Small business owners and shopkeepers (other) & & & & 1 & & & & & & & & & & & & & & & & & & & & & & & & & & \\
\hline 2.13 Farmers (other) & 1 & & & & & & & & & & & & & 1 & & & & & & & & & & & & & & & & \\
\hline 2.14 People who started working at young age (other) & & & & & & & & & & & & & & & & 1 & & & & & & & & & & & & & & \\
\hline 2.15 People living in tense neighbourhoods (other) & & & & & & & & & & & & & & & & 1 & & & & & & & & & & & & & & \\
\hline 2.16 Car users (other) & 1 & & & & & & & & & & & & & & & & & & & & & & & & & & & & & \\
\hline 3.1 General social harmony & & 2 & & & & & & 2 & & & & & & 7 & & & 2 & 1 & & 1 & & & & & & & & 3 & 1 & \\
\hline 3.2 Income/spending power & & 1 & & 1 & & & & & & 1 & 2 & 1 & & 1 & & & 2 & 4 & & 5 & & & & 3 & & & 2 & & 1 & 1 \\
\hline 3.3 Life conditions & & & & & & & & & & & & & & & & & & 1 & & & & & & & & & & & & \\
\hline 3.4 Public administration and public services & 1 & 1 & & & & & & & & 1 & & & & & & 1 & & & & & & & & 1 & & & & 1 & 1 & \\
\hline 3.5 Environment protection & & & & & & & & & & & & & & & & & 1 & & 1 & & & & & & & 1 & & & & \\
\hline 3.6 Health & 1 & & & & & & & & & 1 & & & & & & & & & & & & & & & & & & & & \\
\hline 3.7 Security & 1 & 1 & & & & & & & & 1 & & & & 2 & & & & & & & & 1 & & & 2 & & & 1 & & \\
\hline 3.8 Education (incl. research) & 1 & & & & 2 & & 1 & & & 4 & & & & 3 & & & & & & & & & & & 1 & & & 1 & & \\
\hline 3.9 Formation/extra training & & & & & & & & 2 & & & 1 & & & 1 & & & & & & & & 1 & & & 1 & & & & & \\
\hline 3.10 Culture & 1 & & & & & & & & & & & & & & & & & & & & & & & & & 1 & & & & \\
\hline 3.11 Fight against financial speculation & & 1 & & & & & & & & & & & & & & 1 & 1 & & & & & & & & & & & & & \\
\hline 3.12 Fight against austerity & & 5 & & & & & & & & & & & & & & 1 & 5 & & & & & & & & & & & & & \\
\hline 3.13 Fight against fraud & & & & & 2 & & & & & & & & & & & & & & & 1 & & & & & & 3 & & & & \\
\hline International solidarity (residual category) & 1 & & & & & & & 2 & & & & & & & & & 1 & & & & & & & & 2 & 1 & & & & \\
\hline Non-responsive justifications & & 51 & & & 37 & & & 92 & & & 60 & & & 61 & & & 118 & & & 79 & & & 73 & & & 44 & & & 22 & \\
\hline TOTAL & & 98 & & & 54 & & & 122 & & & 100 & & & 90 & & & 169 & & & 102 & & & 86 & & & 70 & & & 49 & \\
\hline
\end{tabular}

* E refers to Expansive policy, $\mathrm{G}$ to General policy, $\mathrm{R}$ to Restrictive policy 
Table 1 - Sociological evolution of votes for Mitterrand in 1981 and Hollande in 2012 (percentage of valid votes)

\begin{tabular}{l|c|c|c}
\hline Socio-professional group & $\begin{array}{c}\text { Mitterrand } \\
\mathbf{2}^{\text {nd }} \text { round 1981 }\end{array}$ & $\begin{array}{c}\text { Hollande } \\
\mathbf{2}^{\text {nd }} \text { round 2012 }\end{array}$ & Difference \\
\hline Self-employed (shopkeeper, artisan) & 36 & 30 & -6 \\
\hline Manager, professional & 43 & 52 & +9 \\
\hline Intermediate occupation & 53 & 50 & -3 \\
\hline Non-manual worker & 67 & 57 & -10 \\
\hline Manual worker & 74 & 58 & -16 \\
\hline Inactive, retired & 45 & 46 & +1 \\
\hline
\end{tabular}

Source: Joffré (2013: 157) 
Table 2 - Evolution of responsive justifications according to type of policy (in percentages)

\begin{tabular}{c|c|c|c}
\hline Year & $\begin{array}{c}\text { Expansive } \\
\text { policy }\end{array}$ & $\begin{array}{c}\text { General } \\
\text { policy }\end{array}$ & $\begin{array}{c}\text { Restrictive } \\
\text { policy }\end{array}$ \\
\hline $\mathbf{1 9 8 1}$ & $\mathbf{5 8 . 7}$ & 39.1 & 2.2 \\
1982 & $\mathbf{5 2 . 9}$ & 35.3 & 11.8 \\
1983 & 21.4 & $\mathbf{6 0 . 7}$ & 17.9 \\
1984 & 45.0 & $\mathbf{5 0 . 0}$ & 5.0 \\
$\mathbf{1 9 8 5}$ & 6.9 & $\mathbf{8 9 . 7}$ & 3.4 \\
& & & \\
$\mathbf{2 0 1 2}$ & 20,0 & $\mathbf{6 0 . 0}$ & 20.0 \\
$\mathbf{2 0 1 3}$ & 17.4 & $\mathbf{6 5 . 2}$ & 17.4 \\
$\mathbf{2 0 1 4}$ & 30.8 & 7.7 & $\mathbf{6 1 . 5}$ \\
$\mathbf{2 0 1 5}$ & 21.7 & 26.1 & $\mathbf{5 2 . 2}$ \\
$\mathbf{2 0 1 6}$ & 25.9 & 33.3 & $\mathbf{4 0 . 7}$ \\
\hline
\end{tabular}


Table 3 - Evolution of responsive justifications towards social groups according to type of policy (in percentages)

\begin{tabular}{c|c|c|c}
\hline Year & $\begin{array}{c}\text { Expansive } \\
\text { policy }\end{array}$ & $\begin{array}{c}\text { General } \\
\text { policy }\end{array}$ & $\begin{array}{c}\text { Restrictive } \\
\text { policy }\end{array}$ \\
\hline 1981 & $\mathbf{8 0 . 0}$ & 10.0 & 10.0 \\
1982 & $\mathbf{7 5 . 0}$ & 0.0 & 25.0 \\
1983 & 15.4 & $\mathbf{4 6 . 2}$ & 38.5 \\
1984 & $\mathbf{5 7 . 1}$ & 42.9 & 0.0 \\
1985 & 16.7 & $\mathbf{6 6 . 7}$ & 16.7 \\
& & & \\
2012 & $\mathbf{4 5 . 5}$ & $\mathbf{4 5 . 5}$ & 9.1 \\
2013 & 22.2 & 33.3 & $\mathbf{4 4 . 4}$ \\
2014 & 16.7 & 16.7 & $\mathbf{6 6 . 7}$ \\
2015 & 8.3 & 8.3 & $\mathbf{8 3 . 3}$ \\
$\mathbf{2 0 1 6}$ & 8.3 & 33.3 & $\mathbf{5 8 . 3}$ \\
\hline
\end{tabular}


Figure 1 - Distribution of responsive justifications under Mitterrand and Hollande governments.

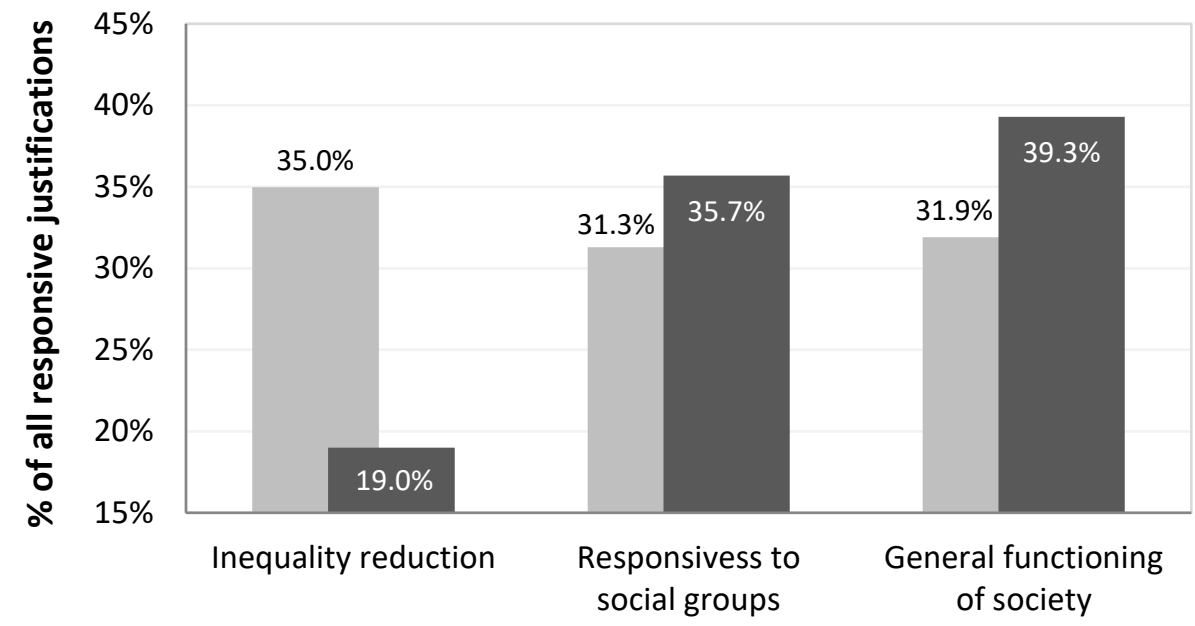

$\square$ Mitterrand governments (1981-1985) $\quad$ - Hollande governments (2012-2016) 
Figure 2. Distribution of responsive justifications towards social groups under Mitterrand and Hollande governments

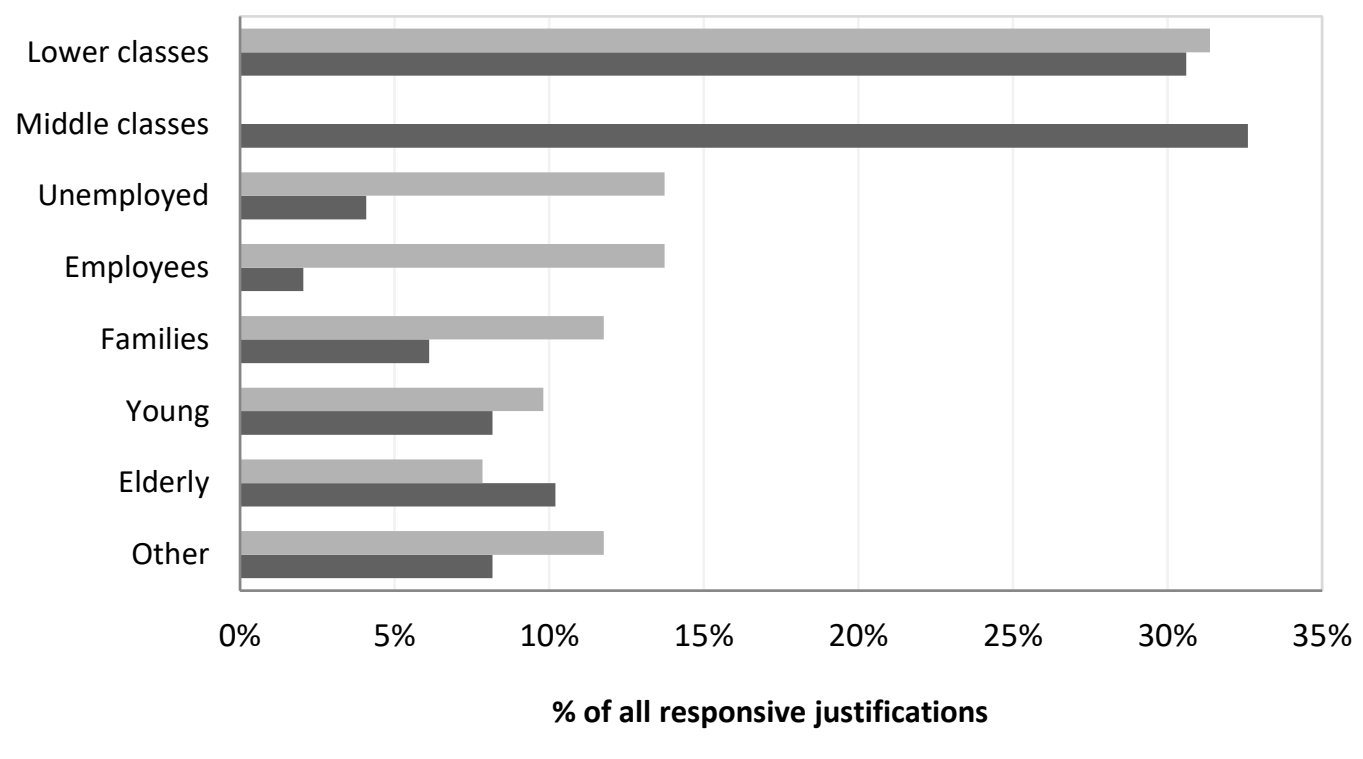

Mitterrand governments (1981-1985) - Hollande governments (2012-2016) 